\title{
The Topic Structure of the Book of Mormon: Worldview Insights for Mental Health Professionals
}

\author{
Paul T. Callister (D) https://orcid.org/0000-0002-7214-3938 \\ Cass Dykeman (D) https://orcid.org/0000-0001-7708-1409 \\ ${ }^{1}$ Oregon State University
}

This in the authors' preprint of a manuscript being prepared for submission to a peer reviewed journal. Comments are invited and can be directed to the first author at callistp@oregonstate.edu

\begin{abstract}
This study examined the spiritually informed worldview of members of The Church of Jesus Christ of Latter-day Saints through exploration of the topical structure of the Book of Mormon sacred text. Latent Dirichlet allocation (LDA) was used to identify the latent topical structure of the Book of Mormon. The two research questions were (RQ1): What is the topical structure of the Book of Mormon?, and (RQ2): How do the level of topics vary by individual subcorpuses within the Book of Mormon? This effort produced a 30topic model. The levels of 30 topics among the sections of the Book of Mormon were detailed. Implications, limitations, and suggestions for further study were presented. In addition, a discussion on how the worldview structures produced by this study can inform the practice of mental health professionals takes place.

Keywords: multiculturalism, CACREP, latent Dirichlet allocation, LDA, artificial intelligence, natural language processing, topic modeling, spirituality, corpus linguistics, Book of Mormon, counseling, worldview, religion, Latter-day Saints, theistic values
\end{abstract}

\section{Introduction}

Since the time of William James, counselors have recognized the interrelationship between spirituality and mental health. Within counseling, both the Council for Accreditation of Counseling and Related Educational Programs (CACREP) and the American Counseling Association (ACA) ethical standards embody James' perspective. Despite this confluence, mental health professionals have been slow to acknowledge and engage in clinical work with this reality. The aim of the present study is to close the gap between professional values and practice.

The CACREP national accreditation standards set forth a variety of multicultural learning goals. One such goal (2.F.2.g) focuses on spirituality. The test of this goal is as follows: "The impact of spiritual beliefs on clients' and counselors' worldviews" (CACREP, 2016, p. 9). Within the U.S., one significant religious and spiritual group consists of members of The Church of Jesus Christ of Latter-day Saints and related Latter-day Saint communities. There are only a few studies related to the relationship between this community's sacred text and meaning-making. As such, 
counselors working with these communities are ignorant of the text their clients rely on for meaning-making and life direction. Such ignorance limits their ability to be clinically effective.

In a review of the literature on the topical structure of the Book of Mormon and the influence of the Book of Mormon on The Church of Jesus Christ of Latter-day Saints and related Latter-day Saint communities, nine key points emerged in reference to the present study. These points were: (a) the definition of scripture, (b) the definition of the Book of Mormon, (c) the nature of authorship in the Book of Mormon, (d) the significance of the Book of Mormon to Latter-day Saint communities, (e) the role of the Book of Mormon in the Latter-day Saint community's worldview formation, (f) definition of topic and topic structure, (g) previous attempts to determine the topic structure of the Book of Mormon, (h) what is latent Dirichlet allocation (LDA), and (i) the definition of extant research on using LDA to study sacred texts.

The word "scripture" comes from the word scribere, meaning to write (Thompson, 1995). It is used to denote writings that are recognized as sacred and inspired (The Church of Jesus Christ of Latter-day Saints, 2019). Within Latter-day Saint communities, scripture is viewed as (a) inspired by God, (b) provides a model for living, and (c) has a role in religious and spiritual development for many people who consider themselves religious or spiritual (Davies \& Madsen, 1992).

Along with the Holy Bible, the Book of Mormon is considered as scripture by The Church of Jesus Christ of Latter-day Saints and members of Latter-day Saint communities. It was first published in 1830 by Joseph Smith, the founder of The Church of Jesus Christ of Latter-day Saints. The book claims to be a record of ancient peoples who lived in the Americas. It contains poetry, narrative texts, sermons and speeches, letters, allegory, metaphor, imagery, typology, wisdom literature, and apocalyptic literature (Rust, 1992).

The Book of Mormon consists of 15 books, each named after the book's primary author. However, the Book of Mormon consists of many writers. The writers include religious and spiritual leaders, community leaders, and record keepers. It also includes other figures whose voices and words are included, as well as preexisting biblical and nonbiblical writings that are included in the text. The Book of Mormon also contains a title page and witness statements, which were included in the original publications.

The initial publication of the Book of Mormon was associated with the establishment of The Church of Jesus Christ of Latter-day Saints in 1830, and Joseph Smith called it "the keystone of our religion" (Woodruff, 1841, p. 112). Like other scripture, the Book of Mormon is considered by Latter-day Saints to be the word of God, and a tool by which one receives personal revelation and inspiration from God (Bushman, 2008). 
The Book of Mormon shapes the worldview of Latter-day Saints. According to Palmer (1996), a worldview is "the fundamental cognitive orientation of a society, a subgroup, or even an individual" (pp. 113-114). The Book of Mormon points to a God who is actively involved with humankind, set the stage for the establishment of a new church of Christ in the latter days, and witnesses of Jesus Christ leading his kingdom through prophets, apostolic gifts, and personal revelation. For those who become members of the Latter-day Saint church, the Book of Mormon lays out a way of viewing all human events, realities, and truths according to the eternal principles of the gospel of Jesus Christ. As such, the Book of Mormon is the foundational text for worldview formation for members of the Latter-day Saint church.

Before proceeding with discussion on the topic structure of the Book of Mormon, attention must be made to definitions of both topic and topic structure. Informally, the term topic refers to groups of words that are associated under a single theme (DiMaggio et al., 2013). More formally, Blei (2012) defined a topic as a distribution over a fixed vocabulary. In reference to topic structure, Blei (2012) noted that it is a hidden (i.e., latent) structure composed of the topics, per-document topic distributions, and the perdocument, per-word topic assignments.

There have been various previous attempts to characterize the Book of Mormon's topical content. A number of researchers have analyzed such things as style variations and author wordprints of the Book of Mormon, with the goal of assessing authenticity claims of the sacred text (e.g., Burgon, 1958; Larsen et al., 1980). Latter-day Saint leaders have provided reference guides to the Book of Mormon, beginning in 1835 (Underwood \& Underwood, 1985). However, these reference guides consist of chronological and alphabetical tables of contents rather than identification of topic structure. Additionally, while there have been numerous commentaries about the Book of Mormon, these also have not identified topic structure. Bean (n.d.) reported on prior text mining in the Book of Mormon in the use of identification of intertext similarities and stated that "although topic models were not employed in this work, it probably could have benefitted from it" (p. 1).

The goal of topic modeling is to identify the hidden (i.e., latent) topic structure from a collection of documents. One approach to this modeling is latent Dirichlet allocation (LDA). LDA is a Bayesian statistical method for identifying topics in documents through machine learning (Blei, 2012). The LDA algorithm contains the following: (a) words per topic and (b) number of topics per document. True to the Bayesian nature of the algorithm, it also contains priors for both words per topic and number of topics per document. These priors are Dirichlet distributions (i.e., a distribution of multiple probability distributions; Ng et al., 2011). These priors serve as hyperparameters for the analysis and hence the name of this form of modeling.

LDA has been used previously to study sacred texts. For example, Siddiqui et al. (2013) used LDA to identify the topics in the Holy Quran. Siddiqui et al. was able to identify the major topics in the surahs (i.e., chapters or sections of the Quran), as well as 
the terms that describe those topics. Another example of LDA use in sacred texts include Qahl (2014), who compared sections of the Quran and Hebrew Bible, to identify text similarities. Qahl found that the Hebrew Bible Deuteronomy text and four Quranic chapters were strongly related to each other. These results demonstrate the utility of LDA in use with sacred text corpuses.

Given the aforementioned research needs and gaps, two research questions were designed to guide this study:

RQ1: What is the topical structure of the Book of Mormon?

RQ2: How do the level of topics vary by individual subcorpuses within the Book of Mormon?

\section{Method}

\section{Design}

The topic model used for the Book of Mormon corpus was LDA, and the data were fit using the variational expectation-maximization (VEM) algorithm as implemented in the topicmodel package in R (Grün \& Hornik, 2011). The data supplied to the topicmodel::LDA function was a document-term matrix with a term-frequency weighting. The number of topics $k$ was set to 30 . All remaining parameters were left as defaults. The unit of analysis was individual words as expressed by a document-term matrix with termfrequency weighting (Grün \& Hornik, 2011), which is also known as a bag-of-words approach.

\section{Corpus}

\section{Register, Sources, and Scope}

The register is sacred texts. The source for the corpus was The Book of Mormon: The Earliest Text (Skousen, 2009). The subcorpuses were the individual books within the Book of Mormon text, plus the title page and witness statements. In the order they appear, these individual subcorpuses were: title page, 1 Nephi, 2 Nephi, Jacob, Enos, Jarom, Omni, Words of Mormon, Mosiah, Alma, Helaman, 3 Nephi, 4 Nephi, Mormon, Ether, Moroni, and witness statements. For both research questions, the whole corpus was used. The token count was 1,231,000, and the type count was 16,511.

\section{Preprocessing}

Yale University Press and the editor gave permission to use the text files of The Book of Mormon: The Earliest Text (Skousen, 2009) for this dissertation study. The files were in ASCII format, and there were no non-ASCII characters. To create the bag-ofwords for LDA analysis, the following preprocessing was done: parsing, tokenization, normalization by replacing uppercase with lowercase letters, punctuation removal, and stop words removal (Sbalchiero \& Eder, 2020). Corpus specific stop words were not 
removed (Schofield et al., 2017). After preprocessing, the total stemmed word count was 121,989. For the stemmed word count by subcorpus after preprocessing, see Table 1 .

\section{Measures}

\section{Word}

For this analysis, a word (also referred to as a token) is defined as a string of letters with a white space before and after.

\section{Bag-of-words}

Bag-of-words refers to all the words in a corpus or subcorpus. In the bag-ofwords, grammar and word order are ignored, and multiplicity of words are retained. This is also known as a document-term matrix with term-frequency weighting (Grün \& Hornik, 2011).

\section{Document}

In LDA, documents may be understood as subcorpuses, which when taken together constitute an entire corpus. In this study 17 subcorpuses were considered: 15 books of the Book of Mormon plus the title page and witness statements.

\section{Beta $(\beta)$ score}

Each word in the corpus was assigned a beta score for each topic, which indicate how strongly each word is associated with each topic. Beta scores range from $0-1$, and the sum of all beta scores in a corpus would equal a beta score of 1 . Thus, lower beta scores indicate a more widely dispersed topic, and higher scores indicate higher topic density (i.e., clearer topic definition).

\section{$\operatorname{Gamma}(\gamma)$}

Gamma scores measure the distribution of topics over documents, and are used to identify which topics are associated with each document (Silge \& Robinson, 2017). Gamma scores range from 0-1. A gamma score of 1 for a certain topic within a book would indicate that a document is completely about that topic; whereas a 0 would indicate a topic is not present in a document.

\section{Apparatus}

R Studio was used for all analyses. The R library used for preprocessing and bagof-words was tidytext (Silge \& Robinson, 2017) and tm (Feinerer, 2011). For LDA, the two R packages used, were topicmodels (Grün \& Hornik, 2011) and ldatuning (Nikita, 2016). 


\section{Data Analysis}

An LDA model with $k=30$ topics was fit to the document-term matrix using the variational expectation-maximization (VEM) method as implemented by Blei et al. (2003). No existing literature related to what number of latent topics exists in the Book of Mormon, although there is a history of exploration of various numbers of $k$ when the number of topics is unknown (Siddiqui, 2013). Various numbers of k, ranging between 10 and 40 were examined and $k=30$ was the best fit. This number allowed a granular examination of topics within books (i.e., a number greater than the number of subcorpuses) and is small enough to render interpretable topics.

For the first research question, beta scores were inspected to evaluate which set of words most strongly characterize each topic. The top 50 beta scores were evaluated for each topic. For the second research question, gamma scores were inspected to evaluate which set of topics most strongly characterize each document. All topics where a gamma score exceeds .100 were reported.

\section{Results}

In terms of RQ1, the results suggested 30 topics in the Book of Mormon. The ten highest ranked terms per topic can be found in Table 2. Complete results can be reviewed on this research project's Open Science Foundation website (https://osf.io/x2hev/). Regarding RQ2, a heat map of topic frequency by subcorpus can be inspected in Figure 1.

\section{Discussion}

The aim of this study was to understand topics in the Book of Mormon as a sacred text of members of The Church of Jesus Christ of Latter-day Saints and related Latter-day Saint communities. The first research question examined the topical structure of the Book of Mormon. The second research question examined how topic frequency varied by books within the Book of Mormon.

\section{RQ1}

In terms of RQ1, the results suggested 30 topics that constitute the topical structure of the Book of Mormon. The topics consist of diverse vocabularies, and some topics appear to be readily identifiable. However, other topics are difficult to label. Given space limitations inherent in an Introduction, Methods, Results, and Discussion (IMRaD) article, only those identifiable topics with the 10 highest betas are addressed (in rank order) in this section. The labels for all 30 topics can be reviewed in Table 2.

\section{Topic 3: Establishment and Collapse of the Church of Christ}


Topic 3 occurred only in 4 Nephi with a high gamma score (.999), indicating this is the only topic of this book. Stems in this topic include references to time (e.g., year), deity (e.g., Christ), church (e.g., church), and people (e.g., people). Taken together, this vocabulary suggests this topic is about religious societies going through changes through time. These words match the narrative of the book, which is about the collapse of the religious society that was established following the visit of Jesus, after his death and resurrection, to the Book of Mormon people, and it appears to be about the establishment and collapse of the church of Christ. The following example of the topic occurs prior to the decline of the church: "And it came to pass that the thirty and fourth year passed away, and also the thirty and fifth, and behold, the disciples of Jesus had formed a church of Christ in all the lands round about" (4 Nephi 1:1). Thus, this topic presents to Latter-day Saint readers how Christ's church can be not only established but lost through sin and apostacy.

\section{Topic 17: "Believe in Christ"}

Topic 17 occurred in 2 Nephi with a low gamma score (.175), indicating this topic is a focus of a small portion of this book. Words include "believe" and "Christ". The topic centers on how the path of redemption is through a proper relationship with Christ. An example of this topic is the invitation of Nephi to "hearken unto these words and believe in Christ" (2 Nephi 33:10). As The Church of Jesus Christ of Latter-day Saints (1988) later gave the Book of Mormon the subtitle, Another Testament of Jesus Christ, this topic emphasizes believing and coming unto Jesus Christ as the central purpose of the whole book.

\section{Topic 12: The Nephites are a Branch of the House of Israel}

Topic 12 occurred only in the book of Jacob and has a low gamma score (.166).

This is one of two topics found in this book, the other being the allegory of the tame and wild olive tree (topic 14). Words of both topics overlap (e.g., fruit, tree, branch);

however, this topic also includes words such as "Israel" and "Christ". These words suggest that this topic is one in which Jacob is applying the olive tree allegory to the Nephites as a branch of the House of Israel, in which the Book of Mormon civilizations have the inheritance of being a part of God's chosen people. Here is sample text from this topic:

Wherefore thus saith the Lord: I have led this people forth out of the land of Jerusalem by the power of mine arm, that I might raise up unto me a righteous branch from the fruit of the loins of Joseph. (Jacob 2:25)

The phrase from this passage, "from the fruit of the loins", highlights the goal of this topic.

\section{Topic 6: Recording on Gold Metal Plates}

Topic 6 occurred in three subcorpuses. The book of Jarom and Words of Mormon both had the same high gamma score for this topic (.998), suggesting this is the only 
topic for these books. The title page had a lower gamma score (.330), and that subcorpus had a second topic. Topic 6 vocabulary include "plate", "record", and "write". This topic appears to be about writing summaries on metal plate records of what the people and kings did. An important part of the history of the Book of Mormon is that it consisted of ancient writings made upon gold metal plates, and writers in these books and title page talk about their writing process. A passage representing this topic is: "An account written by the hand of Mormon upon plates taken from the plates of Nephi" (title page). This topic is significant because it presents the ancient historic process of the sacred text.

\section{Topic 25: Linking to Other Covenantal Acts of Sparing}

Topic 25 occurred only in the book of Omni with a high gamma score (.999), suggesting this is the topic of the whole book. Vocabulary in this topic include "Mosiah", "Zarahemla", "pass", and "preserve". Omni covers a narrative section of the Book of Mormon in which the history of King Mosiah facing war and eventually leading the righteous to peace in a new land of Zarahemla is recounted. This topic appears to be about this section of historical narrative. The following is an example of this topic: "And they departed out of the land into the wilderness, as many as would hearken unto the voice of the Lord" (Omni 1:13). This topic presents to the reader fulfilment of God's promise in the opening of the Book of Mormon to Nephi "that inasmuch as thy seed shall keep my commandments, they shall prosper in the land of promise" (1 Nephi 4:14). Woods (2003) pointed out that Zarahemla can be translated as seed of mercy or seed of the spared. This topic's presence serves as means to link Book of Mormon redemption narratives to New Testament and Hebrew Bible redemption narratives (Head, 2012).

\section{Topic 16: Destroy Wickedness or Be Destroyed}

Topic 16 appeared only in the book of Helaman with a moderate gamma score (.348), suggesting it is not the only topic of the book. Words in this topic vocabulary include "destroy" and "repent". In this section of the Book of Mormon, the prophetleaders emphasize to the Nephite people that they must repent of face utter destruction of their civilization, whereas in prior sections the prophets taught that the people would be cast out of their lands if they did not repent. The word "destroy", in particular, is used in this book in reference to the need to destroy the wicked civilization of the Gadianton robbers among them, and not partake or their inequities, or that they themselves will be destroyed. This topic captures the repent or be destroyed theme present in the Book of Mormon. An example of this topic is: "And except ye repent, ye shall perish; yea, even your lands shall be taken from you, and ye shall be destroyed from off the face of the earth" (Helaman 7:28). Thus, Latter-day Saints are given a model of how God interacts to guide his people through his prophetic servants.

\section{Topic 14: The Tame and Wild Olive Trees}

Of all the topics found, the most recognizable was topic 14. The allegory of the tame and wild olive tree is a subject clearly present in Jacob chapter 5, although the high gamma score (.834) suggests that this topic goes beyond that single chapter and is the 
topic for the majority of the book of Jacob. The allegory is a detailed narrative of thoughtful caring of olive trees and includes dozens of horticultural references (Rust, 1992). The presence of words such as "tree", "fruit", and "branch" directly connect to this story. Jacob credits the allegory authorship to Zenos, an old world and pre-Christian prophet, the allegory may be related to the tree of life motif, and it is also a symbol of the House of Israel being dispersed among the nations of the gentiles and later gathered again. The allegory presents itself as typology but also prophecy and apocalyptic literature, reviewing God's involvement with his covenant people through the end when his vineyard will be burned with fire. The following is an example of this topic: "I will liken thee, O house of Israel, like unto a tame olive tree which a man took and nourished in his vineyard, and it grew and waxed old and began to decay" (Jacob 5:4). The inclusion of this topic was to reinforce that members of the Church of Jesus Christ of Latter-day Saints are organically connected to deity.

\section{Topic 22: The Jaredites Face Destruction}

Topic 22 is one of three topics that occurred in the book of Ether and had a moderately low gamma score (.245). It is related to the ancient civilization of the Jaredites which can be seen in the inclusion of names of particular Jaredites (e.g., Coriantumr, Shiz). It also has references to deity (e.g., Lord), words related to repentance (e.g., repent), and words related to destruction (e.g., battle, destruction, murder). Much of the book of Ether is about the great wars among the Jaredite kingdoms, and the book culminates with the destruction of all the people with the exception of a last king, Coriantumr, and a prophet-writer, Ether, who both witness the utter destruction of the people. This topic elucidates the repent or be destroyed motif active within the Jaredite historical narrative. The following includes words of this topic:

And a part of them fled to the army of Shiz, and a part of them fled to the army of Coriantumr. And so great and lasting had been the war and so long had been the scene of bloodshed and carnage that the whole face of the land was covered with the bodies of the dead. (Ether 14:20-21)

This topic found its way into the Book of Mormon as a warning to the Latter-day Saint faithful against the errors of universalism, the need for repentance, and the pitfalls of unjust rule.

\section{Topic 27: Jesus's Visit}

Topic 27 occurred only in 3 Nephi with a moderate gamma score (.317). In this book, Jesus Christ appears to the Nephites after his death and resurrection, teaches, heals, gives power to baptize, and sets up his church. Whereas the word "Christ" occurred more frequently in 3 Nephi prior to the visit of Jesus, referring to the coming messiah, the word "Jesus" occurred more often during the period of his visit, referring to the presence of the person Jesus. The presence of Jesus among the topic vocabulary, as well as other words such as "bless", "baptize", and "pray", suggest that this topic is related to the period of Jesus's visit. The following is an example of this topic: 
And it came to pass that when Jesus had spake these words, the whole multitude fell to the earth, for they remembered that it had been prophesied among them that Christ should shew himself unto them after his ascension into heaven. (3 Nephi 11:12)

This topic presents the New Testament Jesus as the same Book of Mormon Jesus, the one Lord God Omnipotent of the old and new worlds, so that "there shall be one fold and one shepherd" (3 Nephi 15:17, John 10:16).

\section{Topic 18: Human Experience of God's Guidance}

Topic 18 is present in two subcorpuses. Both the book of Enos and the witness statements had high gamma scores for this topic, .999 and .997, respectively. While it is unexpected that these subcorpuses would share a common topic due to content and narrative differences, the high gamma scores suggest that they were drawn from a single latent topic. Example words in topic 18 include "heard" and "voice". Here are example 8 Right, 8 Left concordance lines from Enos 1:3, 10 for these two words:

I remembered the words which I had often heard my father speak concerning eternal life and the was thus struggling in the spirit, behold, the voice of the Lord came into my mind again.

These concordance lines suggest a theme of human experience of God's guidance. This theme echoes Psalm 29 (e.g., "The voice of the Lord is powerful; the voice of the Lord is full of majesty"). This psalm, most likely drawn from Canaanite, Ugaritic, and SumeroAkkadian sources, contains worship motifs focusing on God's voice and dominion over the cosmos (Van der Westhuizen, 1993; Venter, 2004). Like Psalm 29, topic 18 may represent a worship motif.

\section{Summary of RQ1 Findings}

When viewed as a whole, the topics obtained in the analysis appear to present different facets of how a people stay on track with their relationship with God. Each topic is about (a) deity, (b) humans, and (c) the interactions of both. For example, the allegory of the tame and wild olive tree (topic 14) is a metaphor of God trying through history to get humans to produce good fruit (i.e., to be righteous). As further examples, topics 16,22 , and 25 encapsulate God's relationship to specific groups within the context of a repent or be destroyed theme. Overall, these topics present different facets of a spiritual worldview where God's interactions with humanity is the central and organizing way of seeing reality. Latter-day Saints are given a template and bird's-eye-view for living their lives through this theocentric perspective.

\section{RQ2}

In terms of RQ2 (levels of topics within subcorpuses), the distribution of topics varies by subcorpus. For the most part, each topic occurred in only one subcorpus; the smaller subcorpuses have only one topic, and the larger subcorpuses have more than one topic. Twenty-three of the 30 topics are present in only one book, two topics are present 
in two different subcorpuses (13 and 18), one topic is in three subcorpuses (6), and three topics $(10,21,26)$ do not have gamma scores above the cutoff limit (.100) in any

subcorpus. Topics that do occur in multiple documents tend to do so only in the small subcorpuses documents, and these occurrences may be related to small sample size.

There are four potential explanations for the finding that topics are unique to subcorpuses and for the most part do not cross subcorpus divisions. The first explanation is that the subcorpuses of the Book of Mormon are drawn from separate latent topics. A second explanation is that the topic differences are due to changes in the narrative and historical timeframe. For example, only topics in the book of Ether talk about the Jaredites. A third explanation may be that the writers of different subcorpuses have unique language styles. Writers may use pronouns, other parts of speech, and other specific terms at different rates, and the topic model may detect this. It is possible that some of the topics represent an author ID or subcorpus fingerprint. Finally, a fourth explanation is that the number of topics chosen $(k=30)$ impacted the finding of topics not crossing subcorpus divisions. Taken together, the first three explanations appear to be plausible. It does appear likely that the topic differences may be due to a combination of factors, and it appears that the topics of the Book of Mormon are complex. Regarding the number of topics, it appears that the differences between book topics are due to vocabulary differences and not due to the number of topics chosen.

\section{Limitations}

When considering the results of this study, three limitations should be kept in mind. The first is related to the number of topics selected, which was $k=30$. At present there is no literature regarding the number of latent topics in the Book of Mormon. As such a goal of the present research was topic discovery. Not knowing the number of topics beforehand makes for an unsupervised model and different levels of $k$ impacted the results. This study represents early work in topical analysis of this sacred text, further research may explore different numbers of topics for potential better model fit. A second limitation of this research was the inability of the model to detect identifiable topics in some books. While some topics were easily recognizable (e.g., topic 14, olive tree allegory), other topics were loosely defined (e.g., topics 4, 22, and 30 in the book of Ether), and some were ambiguous (e.g., topics 10, 21, and 26 in Alma). While the bag-ofwords modeling has been useful, it ignores the relationships between words, and more sophisticated algorithms may be needed to detect more complex topics of the Book of Mormon. A third limitation of the study is the subjectivity of interpretation of topics. While there are no wrong answers in a subjective process of topic interpretation, the LDA model only identifies vocabularies, and different people may project different understandings onto the same sets of vocabulary.

\section{Implications for Researchers}

The findings suggest two implications for researchers. The first is regarding the finding that topical structure is centered around book divisions. This finding was not an 
expected result of the research and thus may merit further study. For example, whether this finding is unique to the Book of Mormon among sacred texts may be considered. Future research could examine whether other scripture such as the Doctrine and Covenants, the Hebrew Bible, or the New Testament follow this pattern.

A second implication for future research is regarding potential for further topic modeling. Future topic modeling could be expanded to include the larger corpus of the Latter-day Saint cannon, which includes the Holy Bible, the Book of Mormon, the Doctrine and Covenants, and the Pearl of Great Price. Topics found in this larger corpus would provide further understanding of the Latter-day Saint worldview. As well, while the number of topics chosen in this study $(k=30)$ allowed for granularity and also interpretability, expansion of the number of topics (e.g., 100 topics) would allow for further granularity of the topic model. As well, examining levels of topics present in smaller portions of text (e.g., individual chapters, author, or other book subdivisions) would allow more precision regarding where in the corpus specific topics occur.

\section{Implications for Mental Health Professionals}

The obtained results suggest two key implications for mental health professionals that are either within the Latter-day Saint community or outside of this community. First, for outside professionals these topics aid in an understanding of the spiritual worldview of this population. These topics present a worldview that is centered on God, relationships with God, and how people interact with God, Jesus, and the church. For example, Jacob's topics (12 and 14) teach Latter-day Saints that they are members of the house of God within the Abrahamic covenant, which ties them to him like branches grafted into the olive tree, drawing personal strengthening from the goodness of the roots. While many of the topics presented also occur in both the Hebrew Bible and the New Testament, others were unique to the Latter-day Saint community. The 30-topic configuration discussed in the article present a distinct theistic-infused worldview that may both befuddle and limit the professional unfamiliar with such a worldview. As such, it is incumbent on these professionals to grow in their knowledge of the Latter-day Saint worldview.

Second, this research may also deepen understanding of the worldview of this population for those already familiar with Latter-day Saints. Machine learning is a new approach to understanding the topical structure of the Book of Mormon, and there may be some aspects of the spirituality, religion, and scriptures of The Church of Jesus Christ of Latter-day Saints that may be underappreciated, even by Latter-day Saint professionals and clients themselves. As well, the mined topics may amount to an articulation of core aspects of the Book of Mormon as identified in novel ways by the algorithms which may shine unique light on the faith and worldview of Latter-day Saints. For example, the inclusion of both the Book of Enos and the witness statements in a single topic is a grouping that has not been previously identified. This grouping allowed us to identify a worship motif with words like voice and hear. This provides new understanding of the background of the authors of these books, and adds a spiritual 
depth to these texts. Another example is the finding that most topics do not overlap book, title page, or witness statement divisions, suggesting a diversity within the Book of Mormon and between book authors which may not have been appreciated previously. Taken together, the results of this research provide a refreshed view of the Book of Mormon, which in turn adds a depth of understanding of the Latter-day Saint spiritual worldview.

\section{References}

Bean, M. G. (n.d.). Theological topics through time: An application of Gibbs-sampled LDA and post-hoc metrics to compare religious venues in talks at conferences. Brigham Young University. https://bean5.github.io/research/CLDSGCT-LDAToT.pdf

Bean, M. G. (2016). A framework for evaluating recommender systems. Brigham Young University. Theses and Dissertations. 6195. https://scholarsarchive.byu.edu/etd/6195

Blei, D. M. (2012). Probabilistic topic models. Communications of the ACM, 55(4), 7784. https://doi.org/10.1145/2133806.2133826

Blei, D. M., Ng, A. Y., \& Jordan, M. I. (2003). Latent Dirichlet allocation. Journal of Machine Learning Research, 3, 993-1022. https://www.jmlr.org/papers/volume3/blei03a/blei03a.pdf

Burgon, G. L. (1958). An analysis of style variations in the Book of Mormon. Theses and Dissertations. https://scholarsarchive.byu.edu/etd/4569

Bushman, R. L. (2008). Mormonism: A very short introduction. Oxford University Press.

Chang, J. (2015). lda: Collapsed Gibbs sampling methods for topic models [software]. https://cran.r-project.org/web/packages/lda/

The Church of Jesus Christ of Latter-day Saints. (1988). Since 1982, subtitle has defined book as 'another testament of Jesus Christ'. Church News.

https://www.thechurchnews.com/archives/1988-01-02/since-1982-subtitle-hasdefined-book-as-another-testament-of-jesus-christ-154250

The Church of Jesus Christ of Latter-day Saints. (2019). Scripture. https://www.churchofjesuschrist.org/study/scriptures/bd/scripture?lang=eng

Council for the Accreditation of Counseling and Related Educational Programs. (2016). 2016 CACREP accreditation standards. http://www.cacrep.org/wpcontent/uploads/2017/08/2016-Standards-with-citations.pdf

Davies, W. D., \& Madsen, T. G. (1992). Scripture. In D. H. Ludlow (Ed.), Encyclopedia of Mormonism (pp. 1277-1283). Macmillan Publishing Company.

DiMaggio, P., Nag, M., \& Blei, D. (2013). Exploiting affinities between topic modeling and the sociological perspective on culture: Application to newspaper coverage of US government arts funding. Poetics, 41(6), 570-606.

https://doi.org/10.1016/j.poetic.2013.08.004

Feinerer, I. (2011). tm: Text mining package. R package version 0.5-5 [software]. https://cran.r-project.org/package $=$ tm

Grün, B., \& Hornik, K. (2011). topicmodels: An R package for fitting topic models. Journal of Statistical Software, 40(1), 1-30. https://doi.org/10.18637/jss.v040.i13 
Head, R. J. (2012). Unity and the King James Bible. Dialogue: A Journal of Mormon Thought, 45(2), 45-58. https://www.jstor.org/stable/10.5406/dialjmormthou.45.2.0045

Larsen, W. A., Rencher, A. C., \& Layton, T. (1980). Who wrote the Book of Mormon? An analysis of wordprints. BYU Studies Quarterly, 20(3), 225-251. https://www.jstor.org/stable/43042358

Schofield, A., Magnusson, M., \& Mimno, D. (2017, April). Pulling out the stops: Rethinking stopword removal for topic models. Proceedings of the 15th Conference of the European Chapter of the Association for Computational Linguistics: Volume 2, Short Papers (pp. 432-436).

Siddiqui, M. A., Faraz, S. M., \& Sattar, S. A. (2013, December 22-25). Discovering the thematic structure of the Quran using Probabilistic Topic Model. 2013 Taibah University International Conference on Advances in Information Technology for the Holy Quran and Its Sciences (pp. 234-239). Al-Madinah, Saudi Arabia. https://doi.org/10.1109/NOORIC.2013.55

Shashank, K. (2019). Evaluate Topic Models: Latent Dirichlet allocation (LDA): A stepby-step guide to building interpretable topic models. Toward Data Science. https://towardsdatascience.com/evaluate-topic-model-in-python-latent-dirichletallocation-lda-7d57484bb5d0

Naushan, H. (2020). Topic modeling with latent Dirichlet allocation. Toward Data Science. https://towardsdatascience.com/topic-modeling-with-latent-dirichletallocation-e7ff75290f8

Ng, K. W., Tian, G-L., \& Tang, M-L. (2011). Front matter. In K. W. Ng, G-L. Tian, \& M-L. Tang (Eds.), Dirichlet and related distributions: Theory, methods and applications (pp. i-xxvi). Wiley. https://doi.org/10.1002/9781119995784.fmatter

Nikita, M. (2016). Select number of topics for LDA model. https://cran.rproject.org/web/packages/ldatuning/vignettes/topics.html

Palmer, G. B. (1996). Toward a theory of cultural linguistics. University of Texas Press.

Qahl, S. H. M. (2014). An automatic similarity detection engine between sacred texts using text mining and similarity measures [Master's thesis, Rochester Institute of Technology]. ScholarWorks. https://scholarworks.rit.edu/theses/8496

Rust, R. D. (1992). Book of Mormon literature. In D. H. Ludlow (Ed.), Encyclopedia of Mormonism (pp. 181-185). Macmillan Publishing Company.

Sbalchiero, S., \& Eder, M. (2020). Topic modeling, long texts and the best number of topics. Some problems and solutions. Quality $\&$ Quantity, 54, 1095-1108. https://doi.org/10.1007/s11135-020-00976-w

Sievert, C., \& Shirley, K. (2014). LDAvis: A method for visualizing and interpreting topics. In Proceedings of the workshop on interactive language learning, visualization, and interfaces (pp. 63-70). https://www.aclweb.org/anthology/W14-3110.pdf

Silge, J., \& Robinson, D. (2017). Text mining with R. O'Reilly. https://github.com/dgrtwo/tidy-text-mining

Skousen, R. (Ed.). (2009). The Book of Mormon: The earliest text. Yale University Press. Thompson, D. (1995). The concise Oxford dictionary of current English (9th ed.). Clarendon Press. 
Underwood, G., \& Underwood, G. (1985). The earliest reference guides to the Book of Mormon: Windows into the past. Journal of Mormon History, 12, 69-89. http://www.jstor.org/stable/23285890

Van der Westhuizen, J. P. (1993). A proposed reinterpretation of Psalm 29 based on a stylistic-exegetical analysis. Journal for Semitics, 5(2), 111-122.

https://doi.org/10.10520/AJA10318471 333

Venter, P. M., (2004). Spatiality in Psalm 29. In D. J. Human \& C. J. A. Vos (Eds.), Psalms and liturgy (pp. 235-250). T\&T Clark International.

Williams, C. J. (2001). More light on who wrote the title page. Journal of Book of Mormon Studies, 10(2), 28-29. https://scholarsarchive.byu.edu/jbms/vol10/iss2/5/

Woodruff, W. (1841). Remarks, 28 November 1841. The Joseph Smith Papers. https://www.josephsmithpapers.org/paper-summary/remarks-28-november$\underline{1841 / 1}$

Woods, F. E. (2003). Scripture note: Doctrine and Covenants 125. Religious Educator: Perspectives on the Restored Gospel, 4(1) 87-88.

https://scholarsarchive.byu.edu/re/vol4/iss1/9 
Table 1

Subcorpus Stemmed Word Count After Preprocessing

\begin{tabular}{ll}
\hline Subcorpus & Count \\
\hline Alma & 38,353 \\
2 Nephi & 14,157 \\
Mosiah & 13,845 \\
3 Nephi & 12,832 \\
1 Nephi & 11,374 \\
Helaman & 9,447 \\
Ether & 7,473 \\
Jacob & 4,336 \\
Mormon & 4,189 \\
Moroni & 2,910 \\
4 Nephi & 882 \\
Omni & 605 \\
Enos & 536 \\
Words of Mormon & 363 \\
Jarom & 325 \\
Witness statements & 237 \\
Title page & 125 \\
\hline
\end{tabular}

Note. Total corpus $=121,989$ 


\section{Table 2}

Topic Number, Beta Scores, Words, Subcorpus, and Topic Description

\begin{tabular}{|c|c|c|c|c|}
\hline Topic & Sum Beta* & Top 10 words of topic & $\begin{array}{l}\text { Subcorpus name } \\
\text { (gamma score) }\end{array}$ & Topic description \\
\hline 3 & 0.595 & $\begin{array}{l}\text { pass, year, peopl, came, } \\
\text { away, christ, hundr, also, } \\
\text { among, even }\end{array}$ & 4 Nephi (.999) & $\begin{array}{l}\text { Establishment and } \\
\text { Collapse of the Church } \\
\text { of Christ }\end{array}$ \\
\hline 17 & 0.580 & $\begin{array}{l}\text { shall, god, unto, may, word, } \\
\text { hath, yea, now, men, peopl }\end{array}$ & 2 Nephi (.175) & "Believe in Christ" \\
\hline 12 & 0.553 & $\begin{array}{l}\text { unto, thing, lord, word, thou, } \\
\text { will, fruit, day, wherefor, } \\
\text { saith }\end{array}$ & Jacob $(.166)$ & $\begin{array}{l}\text { The Nephites are a } \\
\text { Branch of the House of } \\
\text { Israel }\end{array}$ \\
\hline 6 & 0.549 & $\begin{array}{l}\text { plate, peopl, king, land, thing, } \\
\text { pass, mani, accord, wherefor, } \\
\text { came }\end{array}$ & $\begin{array}{l}\text { Jarom }(.998) ; \text { title } \\
\text { page }(.330) ; \text { Words of } \\
\text { Mormon }(.998)\end{array}$ & $\begin{array}{l}\text { Recording on Gold } \\
\text { Metal Plates }\end{array}$ \\
\hline 25 & 0.522 & $\begin{array}{l}\text { pass, came, mosiah, lord, } \\
\text { behold, land, peopl, unto, } \\
\text { zarahemla, wilder }\end{array}$ & Omni (.999) & $\begin{array}{l}\text { Linking to Other } \\
\text { Covenantal Acts of } \\
\text { Sparing }\end{array}$ \\
\hline 16 & 0.517 & $\begin{array}{l}\text { yea, peopl, shall, come, now, } \\
\text { unto, word, upon, came, } \\
\text { might }\end{array}$ & Helaman $(.348)$ & $\begin{array}{l}\text { Destroy Wickedness or } \\
\text { Be Destroyed }\end{array}$ \\
\hline 26 & 0.490 & $\begin{array}{l}\text { unto, peopl, will, word, yea, } \\
\text { pass, behold, great, mani, god }\end{array}$ & Alma** & $\begin{array}{l}\text { Prophecy of } \\
\text { Destruction }\end{array}$ \\
\hline 14 & 0.489 & $\begin{array}{l}\text { unto, vineyard, behold, tree, } \\
\text { shall, fruit, will, came, } \\
\text { branch, pass }\end{array}$ & Jacob $(.834)$ & $\begin{array}{l}\text { The Tame and Wild } \\
\text { Olive Trees }\end{array}$ \\
\hline 10 & 0.486 & $\begin{array}{l}\text { unto, god, pass, peopl, came, } \\
\text { land, thing, lamanit, upon, } \\
\text { now }\end{array}$ & Alma** & Ambiguous war topic \\
\hline 22 & 0.483 & $\begin{array}{l}\text { unto, upon, came, peopl, } \\
\text { behold, pass, mani, son, lord, } \\
\text { coriantumr }\end{array}$ & Ether $(.245)$ & $\begin{array}{l}\text { The Jaredites Face } \\
\text { Destruction }\end{array}$ \\
\hline 27 & 0.476 & $\begin{array}{l}\text { unto, pass, shall, peopl, came, } \\
\text { upon, land, come, thing, say }\end{array}$ & 3 Nephi $(.317)$ & Jesus's Visit \\
\hline 18 & 0.475 & $\begin{array}{l}\text { unto, god, peopl, shall, lord, } \\
\text { came, faith, also, father, } \\
\text { record }\end{array}$ & $\begin{array}{l}\text { Enos }(.999) ; \\
\text { Witness statements } \\
(.997)\end{array}$ & $\begin{array}{l}\text { Human Experience of } \\
\text { God's Guidance }\end{array}$ \\
\hline 19 & 0.474 & $\begin{array}{l}\text { unto, came, shall, lord, god, } \\
\text { pass, thing, father, wherefor, } \\
\text { also }\end{array}$ & 1 Nephi (.357) & $\begin{array}{l}\text { Narrative of being led } \\
\text { out of Jerusalem by } \\
\text { God }\end{array}$ \\
\hline 13 & 0.465 & $\begin{array}{l}\text { unto, lord, lamanit, god, } \\
\text { came, peopl, also, behold, } \\
\text { hath, come }\end{array}$ & $\begin{array}{l}\text { Mormon }(.443) ; \\
\text { title page }(.666)\end{array}$ & $\begin{array}{l}\text { Religious perspective of } \\
\text { social destruction }\end{array}$ \\
\hline
\end{tabular}


Destruction of Nephites came, come, peopl, god, even, lord

1

0.457

21

0.457

24

0.454

4

0.452

5

30

0.444

29

0.443

2

0.441

11

8

0.429

20

0.422

15

0.418

23

0.409

9

0.396

7 unto, christ, god, thing,

behold, shall, faith, wherefor, good, may

peopl, unto, will, now, god, shall, behold, therefor, yea,

pass

unto, pass, lord, behold,

thing, also, shall, yea, father,

god

unto, came, pass, lord, land,

peopl, shall, jare, upon, thing

unto, behold, shall, pass,

came, mani, god, land, lord,

year

shall, pass, lord, came,

wherefor, son, said, write,

behold, begat

shall, unto, lord, upon,

behold, will, word, come,

land, great

god, came, unto, land, word,

peopl, thing, shall, also, hath

shall, behold, unto, father,

thing, peopl, will, one, say,

hath

unto, shall, father, will, came,

lord, therefor, mani, word,

command

unto, now, yea, pass, god,

Alma (.332)

lamanit, land, also, came, citi

2 Nephi (.358)

Mosiah (.353)

3 Nephi (.326)

3 Nephi (.357)

peopl, lord, king, now, pass,

Mosiah (.631)

unto, shall, land, yea, might

unto, behold, peopl, shall, yea,

land, now, came, pass,

lamanit

god, came, land, now, behold,

Alma (.209)

lord, know, armi, accord, son

shall, will, one, wherefor, thi,

2 Nephi (.425) by the Lamanites

Come to Christ and

find good

Ambiguous Alma topic

Visions and spiritual

teachings

Jaredite kingdom

Ambiguous Helaman

topic

Narrative story of

Jared and family

lineage

2 Nephi ambiguous

topic

Come unto God and he will save you from

bondage

Jesus's Visit

3 Nephi period before

Christ's visit

Lamanite-Nephite

religious issues

Nephite story narrative with Alma and Mosiah

Lamanite-Nephite

spiritual teachings

Lamanite-Nephite war

Nephi commentary

about events

*Sum of beta scores for top 50 beta scores for each topic

**Gamma score below .100 


\section{Figure 1}

Heatmap of Topic Levels by Books, Title Page, and Witness Statements

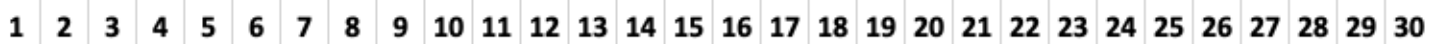

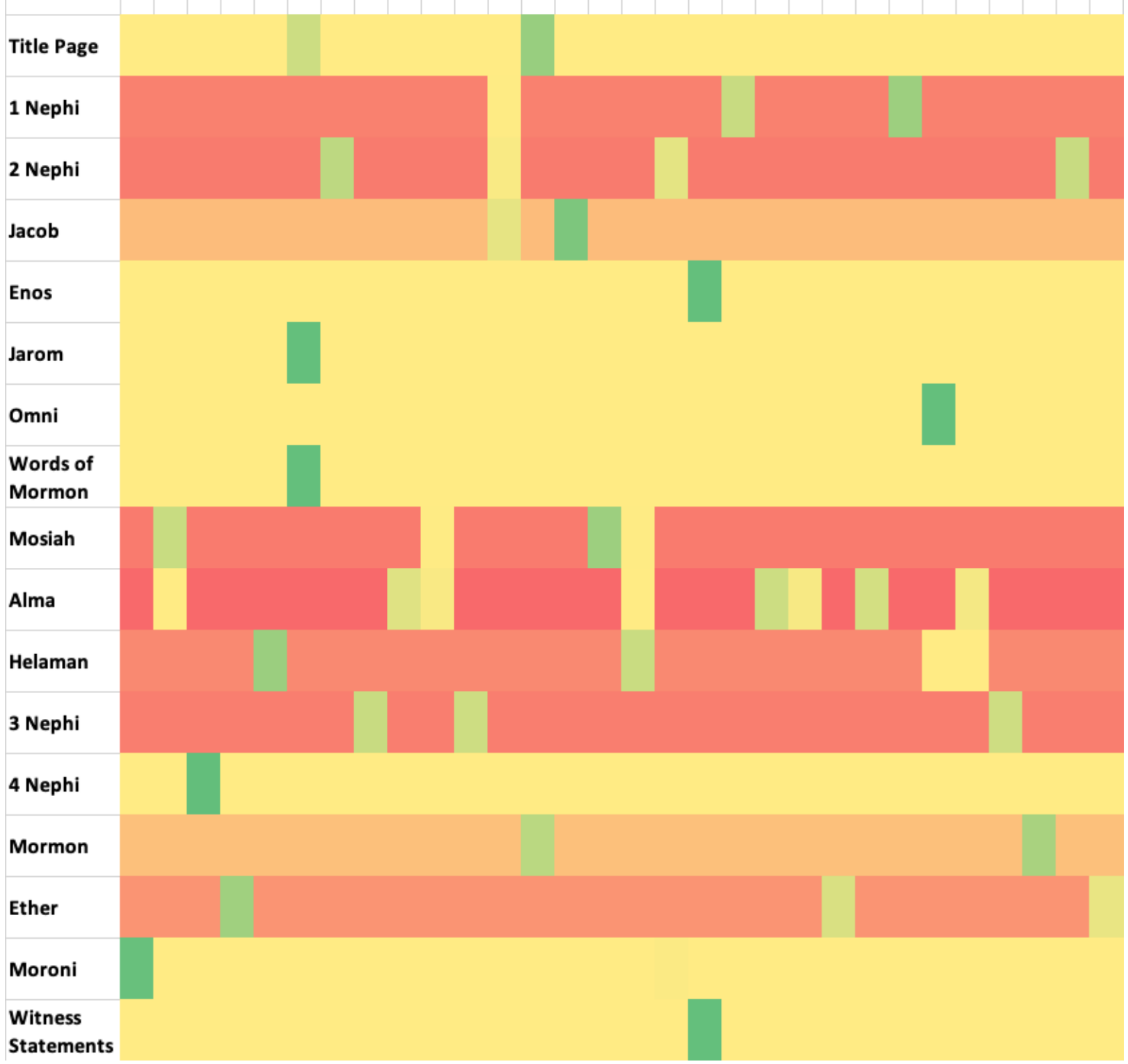

Note. Gamma scores; green $=$ high to moderate; yellow, orange, and red $=$ lower scores approaching 0 . 